\title{
Attitudes toward Policy on Ageing. Results of the Population Policy Acceptance Survey in Austria
}

\author{
Peter Schimany and Katarína Zigová
}

\section{Abstract}

\section{Attitudes to Policy on Ageing. Results of the Population Policy Acceptance Survey in Austria.}

Like all modern societies Austria is faced with the process of demographic ageing. This paper concentrates on the question of how current policies in the field of old-age provision are being viewed and how Austrians envisage this issue for the future. Departing from an assessment of population ageing, results will be presented for the following topics:

- Attitudes towards the state's obligations and responsibilities in the field of social policies;

- Attitudes towards the future design of the pension system;

- Attitudes towards the transition into retirement and

- Preferences concerning the retirement age.

The findings ultimately raise the central question of how, in view of the known economic and demographic conditions, employment and social policy can be better integrated in order to allow older employees to remain part of the workforce for a longer time.

\section{Introduction}

Like all modern societies Austria is faced with the process of demographic ageing. As a result of diminishing birthrates and a continuing increase in life expectancy, the population is getting older. About one third of the Austrian population will be aged $60+$ by 2030 . It can be predicted that the change in age structure will have far-reaching consequences on the state, the society and the individual.

The reform of social security systems, above all the reorganisation of the pension system is of particular importance here. The necessity of reforming the system of old-age income provision is undisputed and hence it is on the political agenda in almost all Western welfare states. For in view of current demographic developments and the situation in the labour market, the current pension system (in its form as a pay-as-you-go contributions system) will cease to be financially viable. There are 
multiple factors which are gradually weakening the pension system. First of all, there is continuing unemployment, partially substituted by atypical employment forms with mandatory pension contributions. Furthermore, there is a proportional shift from contribution-payers to pensioners, who have longer pension lifetimes than before. Faced with these conditions, the interconnected social security systems obviously cannot avoid a quasi-financial crisis. Simultaneously, there is a growing amount of individuals who must expect lower pensions, given their discontinuous employment and individualisation of their life course. As Tálos (2003) states, the aim of social integration in ageing, assurance of a life standard, is at high risk. And hence, the reassessment of the pension benefits is needed. This is mainly to maintain the social equality within and between the generations. The following summary illustrates the relationship and mutual interactions between the pension system and long-term demographic and economic trends (see summary 1).

Summary 1: Relationship between pension system and demographic and economic trends

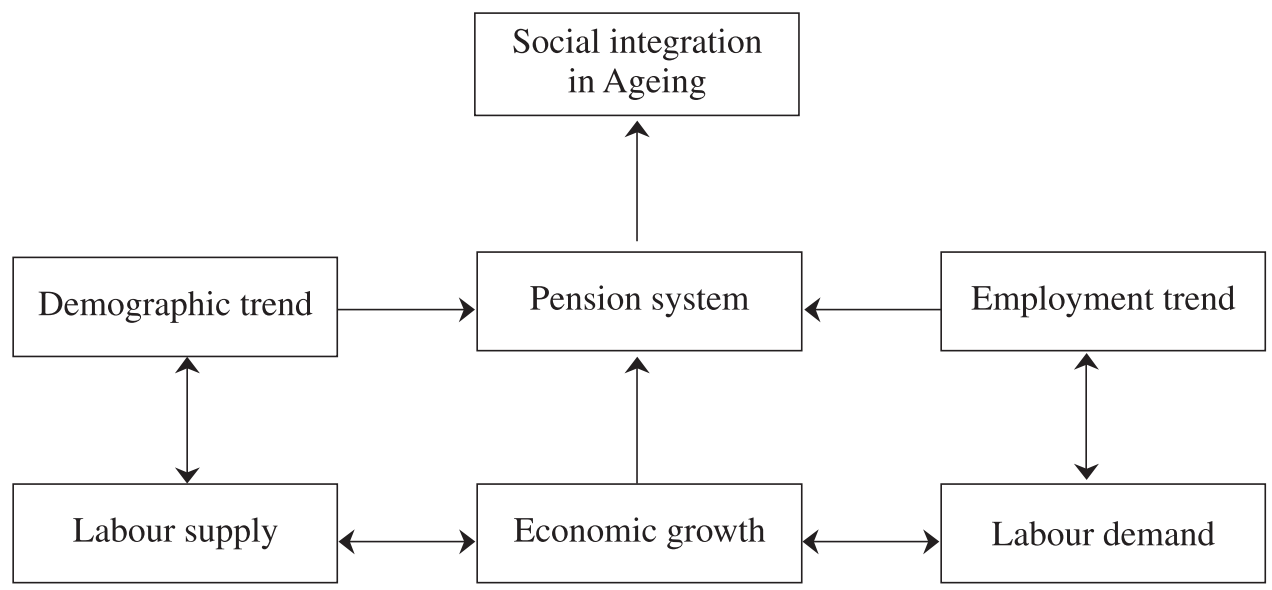

Measures to accommodate the pension system to the changing society are receiving controversial assessments in the public. Until this time, the discussion about pension reforms in Austria just as in the rest of Europe has concentrated on changes in the contribution and benefit parameters. Other aspects, such as measures for the "promotion of active ageing", i.e., the integration of elderly persons in the labour market and the extension of their participation in employed work, have only most recently come to the attention of policymakers (Guger/Mayrhuber 2001). ${ }^{1}$ Actions promoting the employability of older workers can have double positive impact. They can strengthen the economic potential of the country in terms of innovation and

1 In the broader sense the notion of "active ageing" relates not only to labour market participation, but also to activities linked to the household, to support and care for other persons, involvement in community life, leisure time organisation and continuing education (for more details, cf. Avramov and Maskova 2003). 
growth while moderating the financial burden of pension system. In an international comparison Austria shows a relatively lower employment ratio of the age group from 55 to 64 . Similarly, when comparing the average age at entry into retirement, Austria attains only the fourth place from the bottom with roughly 59 years (cf. Figure 1).

Figure 1:

An employment ratio of the age group from 55 to 64 and an actual age at entry into retirement. International comparison (2001)

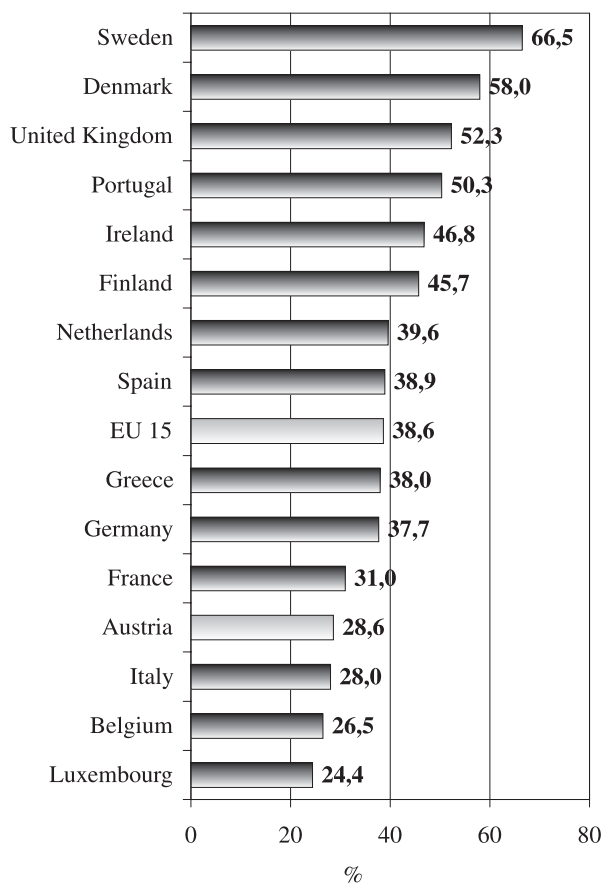

Employment ratio of the age group from 55 to 64 Source: Eurostat.

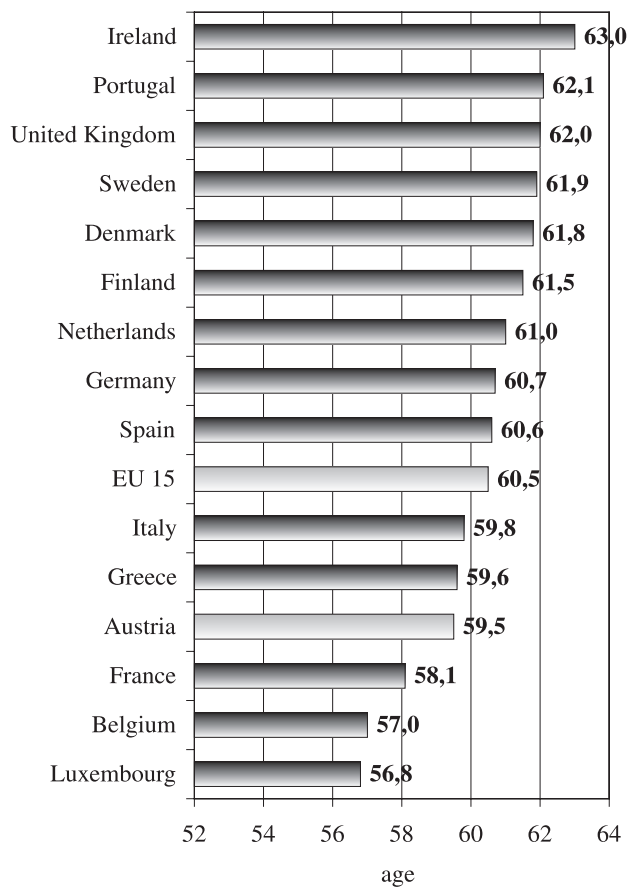

Actual age at entry into retirement

However, the reform discussion is being held largely among scientific and political experts. The population as the target of any socio-political measures is hardly involved at all, although it is evident that the social acceptability of any reform concept bears considerable relevance both for its political enforceability and its long-term sustainability. What is therefore necessary is research looking into the expectations of the pension system as well as into opinions about its proposed reforms from the perspective of the population. Therefore, in this paper we concentrate on the question of how current policies, in the field of old-age provision, are being viewed by the public. Furthermore, we investigate how Austrians envisage this issue for the future.

The structure of the paper is as follows: Section 2 introduces the survey data from both rounds of the PPA questionnaire, along with some specific features of both of them. Section 3 deals with an assessment of population ageing as viewed by the pub- 
lic, with regard to the challenges the process offers, or the problems it might bring. Finally, in Section 4, we discuss the following issues in detail:

- Attitudes towards the state's responsibilities in the field of social policies (see 4.1),

- Attitudes towards the future design of the pension system (see 4.2),

- Attitudes towards the transition into retirement (see 4.3) and

- Preferences concerning the age of retirement (see 4.4).

Section 5 gives a conclusion. Here, we briefly summarise the results and possible policy implications. The findings presented show that public support of any type of pension reform is limited. Nevertheless, there are some signs of acceptance, and it is in particular the complex policy of "active ageing" which seems to meet public preferences. In fact, ageing of the labour force is the most relevant factor affecting a labour market. Therefore, the pension reform cannot be separated from an age-oriented labour market policy. Moreover, an integration of the labour market policy and employment policy is needed.

\section{Data basis}

The results were gathered from the international study "Population Policy Acceptance Survey (PPA)". This survey, which concentrates in particular on the areas "Family and Fertility", has been conducted twice already. In Austria the survey was carried out in 1992 (PPA1) and in 2001 (PPA2). These were representative interviews, with approx. 1.500 (PPA1) and 2.000 (PPA2) Austrian respondents aged 20-54 and 20-64, respectively, being interviewed on the basis of a largely standardised questionnaire.

Both surveys were partly based on the same questionnaire. For comparable items, the samples were unified with respect to the age brackets. This allows at least a partial comparison of two cross-sectional surveys. This gives the possibility to analyse relevant attitudes towards ageing and the policy for the aged in a long-term perspective. The research tool also provides a way to evaluate the Austrian results as well as those obtained for other European countries in a comparative fashion. ${ }^{2}$

\section{Opinions about the ageing population}

According to recent population projections, the total population numbers will still be growing in Austria for about 25 years because the negative birthrate balance can be compensated by immigration for the time being (Hanika 2001). The age struc-

2 For details on the study concept, cf. Schimany (2003). For detailed results, cf. Schimany (2002). 
ture of the Austrian population, however, will see significant changes already in the near future. Children under 15 will be decreasing both in numbers and proportion. At the same time, the labour force, i.e., the population aged $15-60$, will see a continuous decrease. On the other hand, there will be a considerable increase very soon for the population aged $60+$ because more sizeable vintage cohorts than before are now approaching their retirement age. The "demographic breathing space", which up to now was available with regard to the imminent population ageing process, is therefore already over now for Austria. The following illustration clearly shows the future development of the population by broad age groups (cf. Fig. 2).

Figure 2:

Development of the Austrian population 2000-2050, by broad age groups

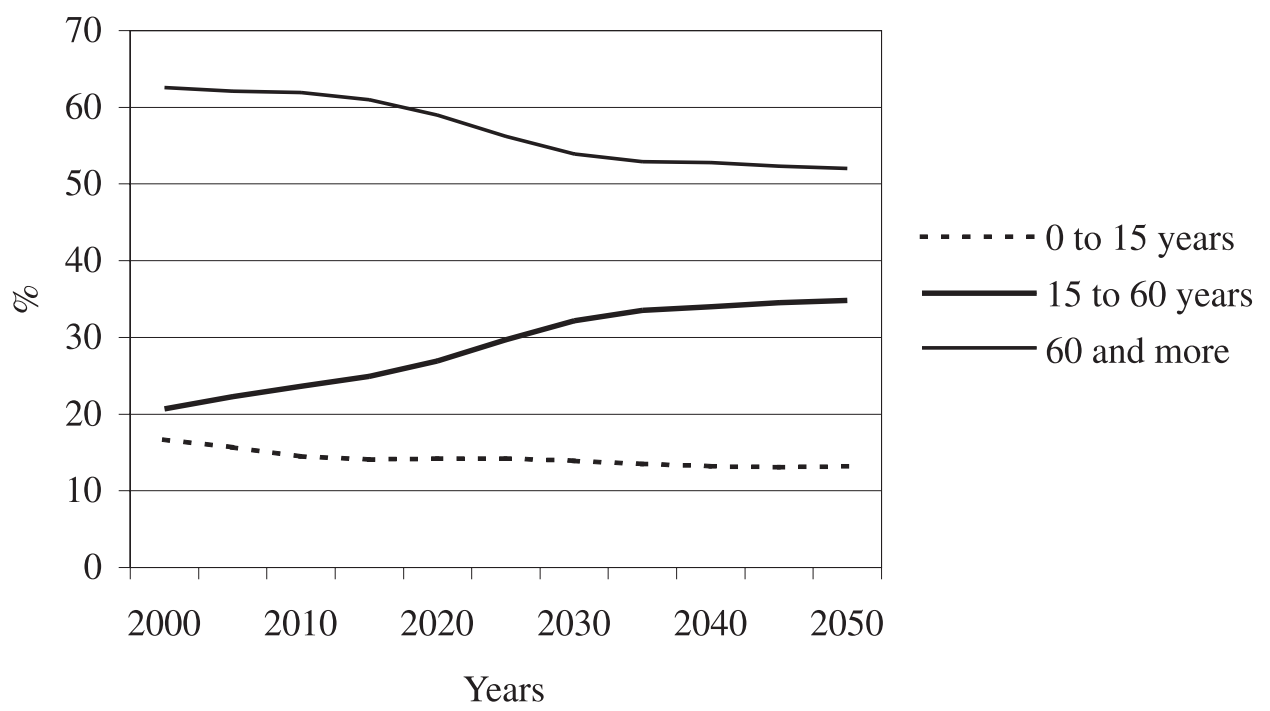

Note: Middle variant. Based on calculations from Statistics Austria.

Source: Hanika (2001:630).

In this context, respondents were asked to give their opinion on the future increasing proportion of aged persons in the total population. If we first take a look at the 2001 survey results, there is the following picture (cf. Fig. 3): about one fifth of the respondents $(21 \%)$ see positive aspects in the fact that the society is ageing, while about half of them (42\%) take a neutral position on this issue. The high percentage of individuals who were "not sure" shows that many people remain uncertain about the challenges and the opportunities of the ageing population. More than one third (35\%), however, have a negative view of this ageing process. This could lead to the conclusion that the future increasing proportion of aged persons in the total population also provokes a number of fears in many individuals.

Differentiating individuals by social characteristics reveals the following picture: There are no significant differences by age groups or by gender. Younger individuals and males assess the process of ageing slightly more negatively than older respon- 
dents or females. Somewhat higher variations are observed when differentiating by education level or income. It is in particular individuals with higher education level and higher income who consider ageing more negatively. This is valid for both surveys. Similarly, individuals for whom religion is an important part of their life evaluate the process of ageing a lot more negatively than respondents who state that religion is not playing any role at all for them.

Compared with the survey made in 1992, however, the proportion of respondents giving a negative view of population ageing has clearly diminished (cf. Fig. 3). At the same time, the number of individuals who see it in a positive light is now ten times higher. Obviously, the ageing society evokes increasingly positive associations. Or, under a more matter-of-fact aspect: the approach of an irreversible change is being anticipated.

Figure 3:

Assessment of population ageing - comparison PPA1/PPA2 (1992/2001)

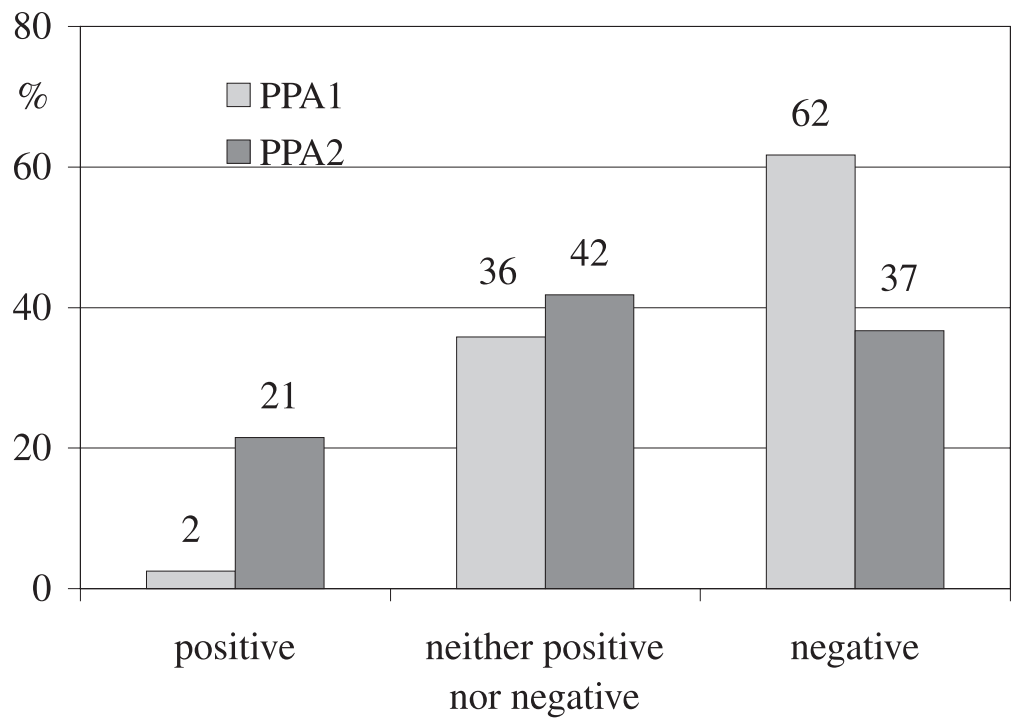

Note: The exact wording of the question was, "The proportion of people aged 60 years and over is expected to rise sharply in the future. How do you rate this process?"

Source: PPA II, Question G1; PPA I, Question 57.

\section{Attitudes towards policies for the aged}

In this section we investigate the assessment of old-age provisions (see 4.1) and of the pension benefits system (4.2). Furthermore, we introduce the attitudes towards the transition into retirement (see 4.3) and preferences towards the age of entry into retirement (4.4). 


\subsection{Attitudes towards the state's responsibilities in the field of social policy}

As the Austrian state provides, compared to other countries, a large-scale and rather generous social security (Schmid 2002), welfare-state benefits receive high acceptance in the population (Reßler 2002). Despite some tendencies towards liberalisation and rising contribution burdens because of economic and social structural problems in connexion with industrial and sociodemographic change, there is no evidence for an increasingly or even fundamentally negative attitude toward the welfare state system in Austria. This is also indicated by the respondents' attitudes towards the state's socio-political responsibility. At the same time, it can be clearly seen what relevance the population assigns to old-age policies in comparison to other fields of policy. In this respect one should consider that in Austria, a person's material security in old age is to a large extent dependent on benefits coming from the public old-age security systems (Wöss 2002:92). ${ }^{3}$

In general, the state's responsibility in the field of social policy is deemed to be very high (cf. Fig. 4). By far the greatest responsibility is assigned to the state in the fields of "old-age provision" (93\%) and "labour market policy" (92\%). This opinion is being held by all groups, that is, independent of specific characteristics of the respondents such as age, sex or class to roughly the same extent. A comparison with the PPA1 data also shows that the state's responsibility in the field of old-age provision is invariably assigned considerable importance: $94 \%$ compared to $93 \% .^{4}$

3 In Austria, the system of old-age provision rests largely (90\%) on the state pension systems and only $10 \%$ comes from private and company pensions. In international comparison the share of the state's contribution is thus relatively high since even in Germany, this share is only at slightly more than $80 \%$.

4 The distinctly higher percentage of $84 \%$ for the policy field "provision of suitable accommodation" in 1992 has to do with a strong immigration wave. This was as a consequence of the conflict in former Yugoslavia. As a result, there was a temporary shortage of low-price accommodation in the private housing market at the time. 
Figure 4:

Attitudes towards the state's responsibility in the field of social policy-comparison PPA1/PPA2

The state is entirely or rather responsible\&

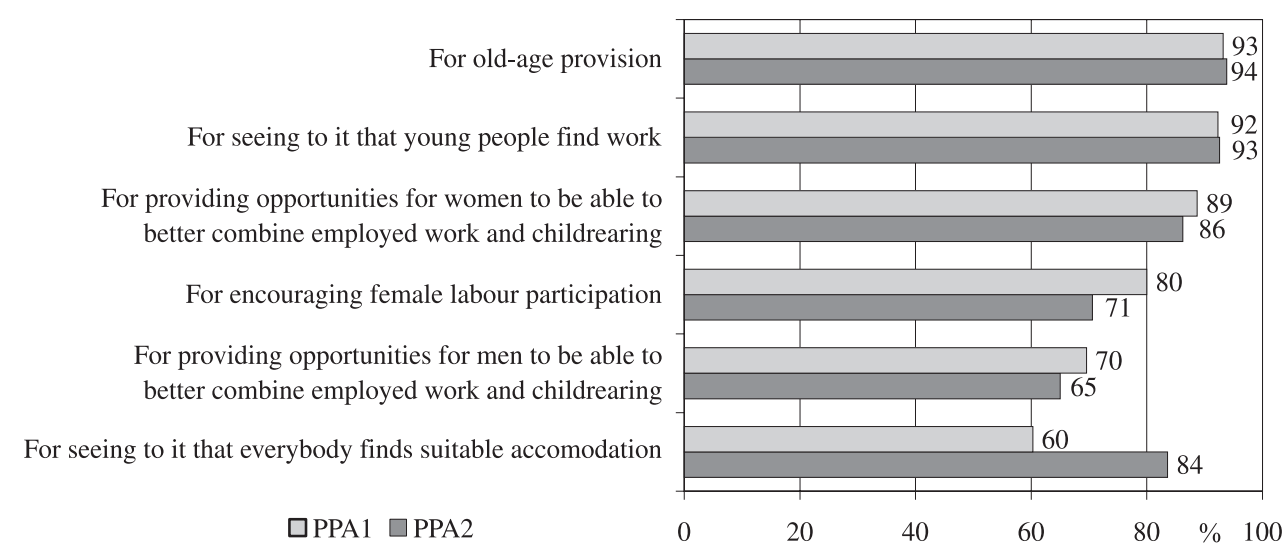

Note: Categories "entirely responsible" and "rather responsible" are aggregated here.

Source: PPA II, Question B1; PPA I, Question 4.

When comparing the state's activities during the last few years in a number of political fields, the results are as follows (cf. Fig. 5): according to most respondents, no other field — with the exception of the social problem of "Families in poverty"- has received less attention in the past than that of old-age provision $(30 \%$ and $24 \%$, respectively). Conversely, again with the exception of "Families in poverty", people think that in all other political fields more has been done than in matters of old-age provision (17\% and $21 \%$, respectively).

Among those respondents who think that the state have done comparatively little in the field of old-age provision in recent years, there are several groups who differ noticeably from the average (24\%). These are, among others, single parents and unemployed persons as well as generally people coming from structurally backward regions. Quite evidently, in all these cases the government transfer income is of particularly high importance for subsistence. It is surprising that this evaluation hardly shows any difference by main age groups: the 50+ group only has a slightly more critical opinion than the $20-34$ as well as the $35-49$ age groups (26\% vs. $22 \%$ and $23 \%)$. This is also true when controlling for other variables. However, we observed an interesting variation inside the age groups here. This might support the thesis that "social equality" is also the problem of "system losers" and "system winners" within one generation, rather than only the problem between young and old. 


\section{Figure 5:}

Assessment of the state's activities in recent years in a number of political fieldsresults of PPA2 (2001)

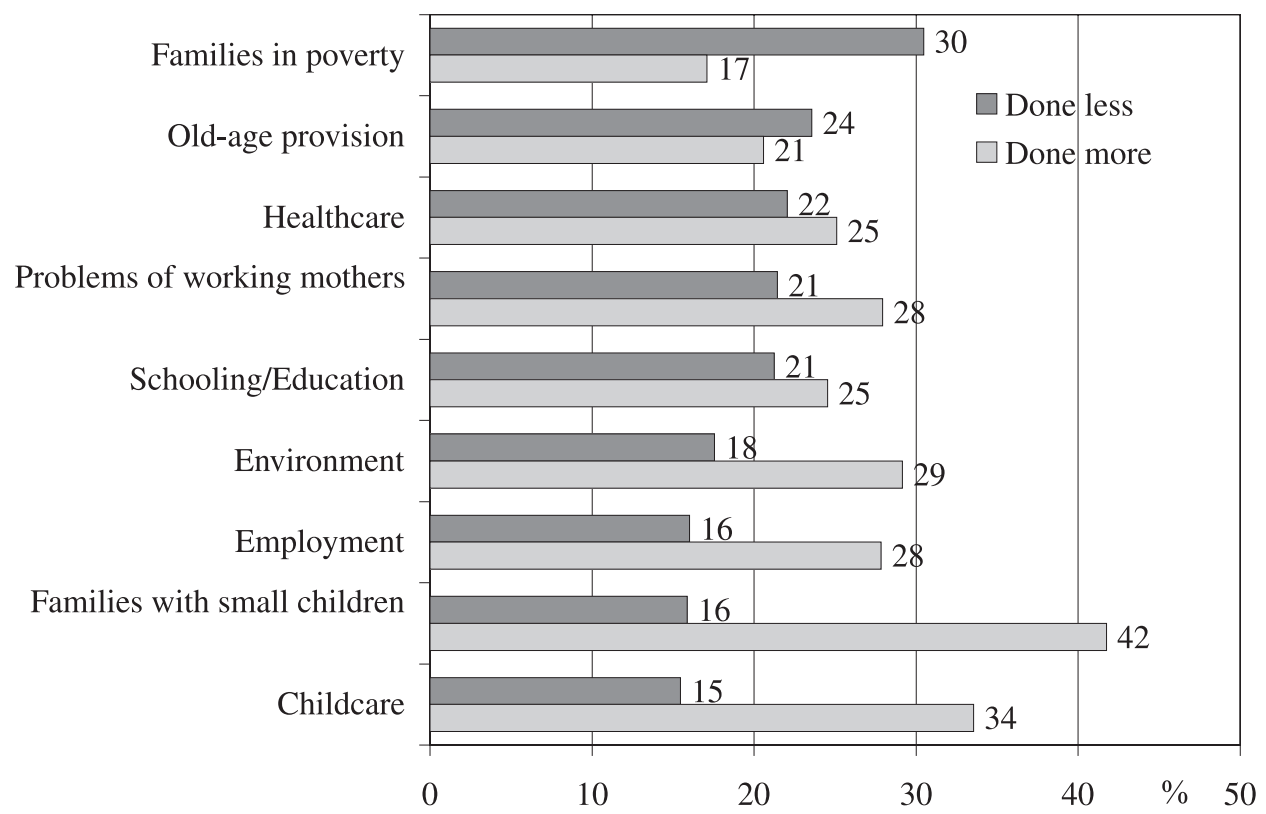

Note: The exact wording of the question was, "According to your opinion, in recent years the state has paid less, more or the same attention than before, to the following issues?"

Source: PPA II, Question B2

To summarise, we see that the state's responsibility in the field of social policy is still attributed a very important role. Therefore there is no reason to speak about a decline in the public acceptance of the welfare state. Furthermore we find that in comparison to other political fields the state is assigned a particularly strong responsibility in matters of old-age provision. In the respondents' opinion, however, it is just the field of old-age provision that has received less attention in recent past than other fields of politics. Because of the central importance that people attribute to old-age security, the state's efforts in terms of old-age provision are obviously receiving very critical views.

The survey did not ask for any reasons for this critical assessment of old-age provision measures. However, the data suggest certain inferences about what reform options would be most accepted by the population.

\subsection{Attitudes towards the future design of the pension system}

The development in growth and structure of the population on the one hand and the process of the labour market and employment on the other show that under the current conditions as well as in the future the present pension system cannot be main- 
tained without changes. There are several indicators to corroborate this, such as the development of the old-age quotient and the pensioner ratio (Wöss 2002:93). ${ }^{5}$ Any political options for reforming the pension insurance system will therefore have to concentrate on stabilising the revenue basis and to react to the demographic change.

If the respondents had their say, the current pension system would be kept largely without any changes. This is implied by the results shown in Figure 6. At any rate, there seems to be no definite preference for any of the suggested possibilities among the population. What respondents would still like the most are an increase of the pension insurance contribution, and the abolition of early retirement possibilities (43\% and $36 \%$, respectively). Increasing the retirement age, on the other hand, is preferred only by one fifth (20\%) of the respondents. And lowering the amount of pension allowances is only seen as an acceptable way of reforming the pension system by a very small minority $(7 \%)$.

The other two measures suggested in the survey will not be dealt with here since these are not measures inherent to the system that would be compatible with current pension law (Schimany 2002). On the one hand, benefits for families should be financed by way of the tax system, and on the other, there would be constitutional objections concerning any obligation of children to support their parents financially in old age. ${ }^{6}$

5 The old-age quotient is defined as follows: population aged 60+ years per 100 of population aged $20-59$ years. The definition of retirement rate is the number of pension benefit receivers per 1000 contribution payers. Indeed, it is expected that legislation in the future will tighten the payment obligations of adult children for senior citizen home accommodation cost incurred by their parents. Currently, the relation between old-age provision and parenting is being intensively discussed. In particular, a "pension linked to the number of children" and "contribution increase for childless individuals" have been demanded. The essential necessity of pension reform is actually linked to increasing childlessness. Hence this should be also one consequence of the pension system. Parents will be penalised, while the childless will be privileged. For the detailed discussion, where the number of children in pay-as-you-go financing of the pension benefits is taken into account, cf. Konrad and Richter (2003). 


\section{Figure 6:}

Preferences with regard to measures for a pension reform - results of PPA2

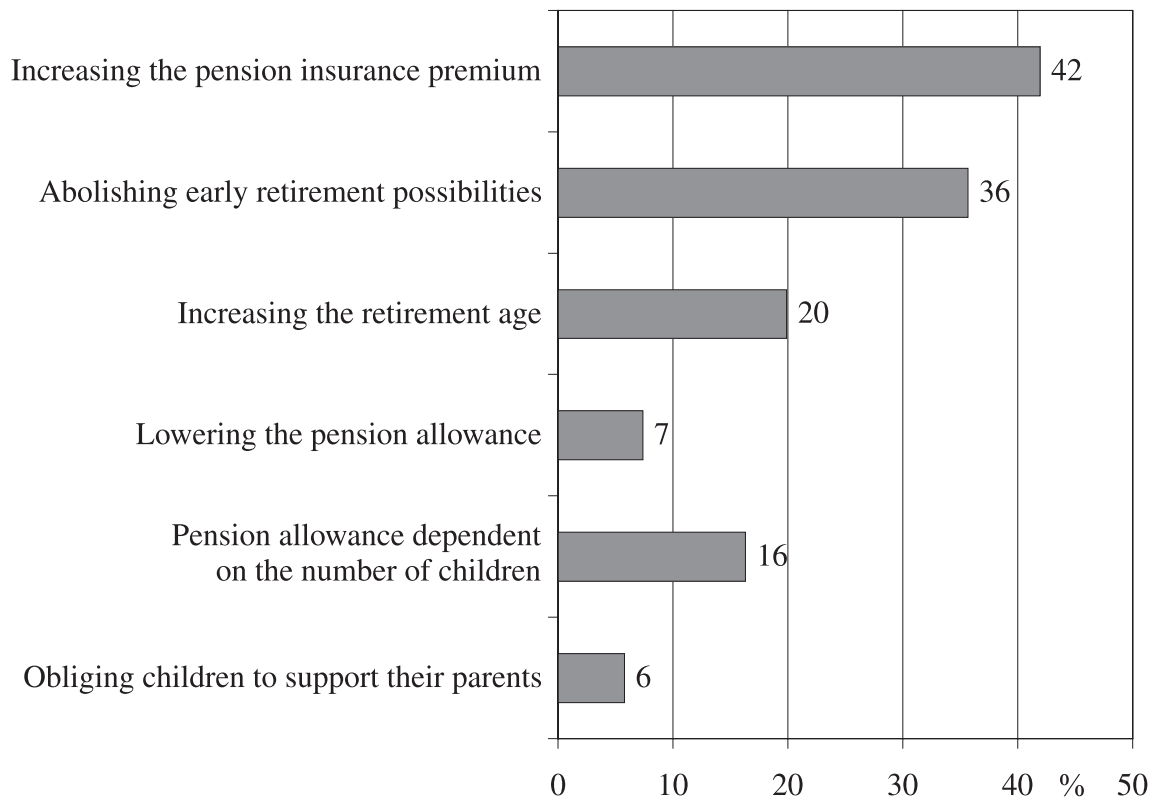

Note: The exact wording of the question was, "There are several ways in which the state could ensure that it will be possible to finance old-age benefits in the future. If you had to choose, which of the following ways would you prefer?"

Source: PPA II, Question G6.

When differentiating respondents by social characteristics, there is the following picture: a selection by age and sex hardly shows any difference-women tend to favour increasing the retirement age slightly more while men give a somewhat higher preference to increasing the pension insurance contribution and lowering the pension allowance. Other social characteristics, such as the marital status or the existence of children in the family, do not provide any sharp boundaries either.

Greater differences are to be found when considering features such as education, income and political preference (cf. Summary 2). Persons with higher educational levels and higher incomes agree with increasing pension insurance contributions and the retirement age, respectively, more often than on average. Persons with low education and low income levels, on the other hand, show under-average approval of any proposal to change the pension system. The extent of approval to any option is thus largely dependent on the socio-economic status of the respondents. And this is true basically for all age groups and both sexes.

Another finding was that the extent of approval varies-though not so clearly — with the preferred political party. Respondents with a preference for the ÖVP (Austrian People's Party) were among those who were still most open-minded about a comprehensive pension reform, while those with a preference for the FPÖ (Freedom Party) on the whole tend to oppose any type of pension reform particularly 
strongly. However, no option received approval regardless of party preference. This result supports the assessment in the political discussion that any pension reform that is to be sustainable in the long run can only be realised as a joint venture by all political parties.

\section{Summary 2:}

Extent of approval to pension reform options, by respondents' social characteristics—results of PPA2

\begin{tabular}{|c|c|c|c|c|}
\hline \multirow[t]{2}{*}{ Characteristic } & \multicolumn{4}{|c|}{ Options } \\
\hline & $\begin{array}{l}\text { Increasing the } \\
\text { pension insurance } \\
\text { contributions }\end{array}$ & $\begin{array}{c}\text { Abolishing early } \\
\text { retirement } \\
\text { possibilities }\end{array}$ & $\begin{array}{l}\text { Increasing the } \\
\text { retirement age }\end{array}$ & $\begin{array}{c}\text { Lowering the } \\
\text { pension allowance }\end{array}$ \\
\hline Lower education & - & - & $-/ *$ & $=$ \\
\hline Higher education & + & + & $+l^{*}$ & $=$ \\
\hline Lower income & - & $-l^{*}$ & $-/ *$ & - \\
\hline Higher income & + & $=$ & + & $+/ *$ \\
\hline \multicolumn{5}{|l|}{$\begin{array}{l}\text { Preferred party: SPÖ } \\
\text { (Social Democrats) }\end{array}$} \\
\hline $\begin{array}{l}\text { Preferred party: ÖVP } \\
\text { (Christian Democrats) }\end{array}$ & $\begin{array}{c}+ \\
-/ *\end{array}$ & $\begin{array}{l}-/ * \\
+/ *\end{array}$ & $\begin{array}{c}- \\
+/ *\end{array}$ & $\begin{array}{c}- \\
+/ *\end{array}$ \\
\hline $\begin{array}{l}\text { Preferred party: FPÖ } \\
\text { (Freedom Party) }\end{array}$ & $\begin{array}{c}-/ * \\
+\end{array}$ & $\begin{array}{l}- \\
=\end{array}$ & $\begin{array}{c}- \\
+/ *\end{array}$ & $+{ }^{*}$ \\
\hline $\begin{array}{l}\text { Preferred party: Grüne } \\
\text { (Green Party) }\end{array}$ & & & & \\
\hline
\end{tabular}

Note: Extent of approval: - below average; + above average; = average. $*=95 \%$ significance level of probability of deviation. The deviations are robust when considering males or females separately, as well as the three main age groups: 20-34, 35-49, 50-64.

Source: PPA II, Question G 6.

\subsection{Attitudes towards the transition into retirement}

The preferences in regard of the future design of the pension system show the following ideal pattern: the majority of respondents refuses lowered pension allowances and a delayed entry into retirement. Instead, however, there is a certain willingness to give up existing encouragements to leave the workforce prematurely and to accept higher contributions to the pension insurance, in order to collect pension allowances in the same amount as today. This option assumes a rigid pension system. What would also be imaginable, however, is a flexible transition into retirement by developing smooth models such as part-time work for the elderly.

In the context of demographic change, there are various reasons for a flexible transition into retirement, namely reasons of pension law, labour market policy and social gerontology. Firstly, the general situation of the pension insurance will force people to longer working lives in the future. Models of flexible transition help the elderly to remain in the working system longer than before, which relieves the pension 
system. A second aspect is that projections of the demographic transformations assume the workforce potential to change in terms of numbers and age structure. It is supposed that the decreasing potential of employed persons and the simultaneous decline of younger people in the workforce cannot be compensated just by increasing the female labour participation and by immigration alone. Models of flexible transition into retirement contribute to integrating the elderly into the workforce and also introduce a longer working lifetime in the future (Clemens 2001:187). Thirdly, there are reasons of social gerontology in favour of the "flex retirement" concept, propagated in the 1970s, which provides for a gradual shortening of the working time after reaching a certain age so that a measured transition into life after working can be achieved (Morschäuser 1999:175).

The results concerning the desired form of this transition (cf. Figure 7) show that only about one out of ten (12\%) of the persons want to maintain the current rigid system. While more than half of them (53\%) do favour the traditional system, they would want the option to be allowed to do some work after retirement. Over one third (36\%), however, prefer a flexible transition into retirement. This result shows that models for a smoother transition do find acceptance among the population.

\section{Figure 7:}

Preferences concerning the transition into retirement-results of PPA2

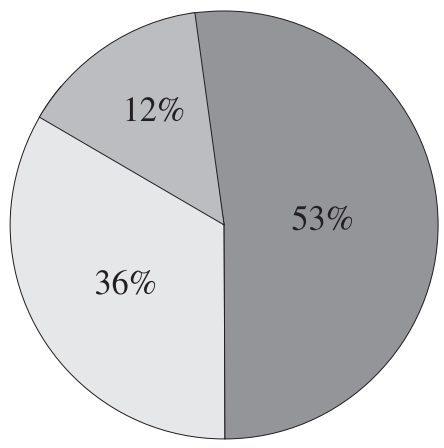

Maintaining the rigid pension system

Maintaining the rigid pension system plus working option in retirement

Flexible transition into retirement

Note: The exact wording of the question was, "Do you think that the policy concerning the transition from work to retirement should be:"

Source: PPA II, Question G11.

Differentiating the persons by social characteristics, we have the following picture (cf. Summary 3): above all, the older generation (45+) prefers to maintain the rigid pension system, while younger respondents (up to age 39) — and also women and people with higher education and higher income-more often desire a flexible transition. The large majority of respondents can thus imagine finishing their working lives in a flexible way and to be "productive" and "active" during retirement. This is an important indicator both for labour market policy and for the politics of civic solidarity. 


\section{Summary 3: \\ Preferences concerning the transition into retirement, by social characteristics— results of PPA2}

\begin{tabular}{|l|c|c|c|}
\hline Characteristic & $\begin{array}{c}\text { Maintaining the rigid } \\
\text { pension system }\end{array}$ & $\begin{array}{c}\text { Maintaining the rigid pension system } \\
\text { plus working option in retirement }\end{array}$ & $\begin{array}{c}\text { Flexible transition } \\
\text { into retirement }\end{array}$ \\
\hline Age $20-34$ & $-/ *$ & - & $+/ *$ \\
\hline Age 35-49 & + & + & $-/ *$ \\
\hline Age 50-64 & $-/ *$ & $=$ & $-/=$ \\
\hline Men & $+/=$ & + & $+/=$ \\
\hline Women & $-/=$ & $-/ *$ & - \\
\hline Income - lower & + & $+/ *$ & $+/ *$ \\
\hline Income - higher & $-/ *$ & $-/ *$ & $-/ *$ \\
\hline Education - lower & + & $-/ *$ & $+/ *$ \\
\hline Education - higher & & + & + \\
\hline
\end{tabular}

Note: The exact wording of the question was, "Do you think that the policy concerning the transition from work to retirement should be:" Extent of approval: - below average; + above average; = average. $*=95 \%$ significance level of probability of deviation.

Source: PPA II, Question G 11.

\subsection{Preferences concerning the retirement age}

The preferences as to measures with regard to the pension reform and the personal desires concerning the transition into retirement gain even more meaningfulness when they are combined with persons' statements about the expected and the desired retirement age. In 2001, the average age at which people actually retired was approx. 58 years for both sexes (cf. Summary 4). The desired retirement age of the interviewed non-pensioners is thus one year below the actual average. However, the retirement age that they are expecting is about four years more than it is in present reality. It can therefore be assumed that the persons already reflect the proposed "increase in the actual retirement age" in their life plans. There is another interesting correlation: persons who wish to become relatively old show a greater approval of increasing the retirement age - and indeed more frequently wish for later retirement. We even observed a significant correlation between expected age and expected retirement age. This is in particular valid for individuals with higher education as well as for those with higher income (Rho $=0.20$ and 0.16 ).

If we compare the results of the two surveys, we have the following picture: on average, persons in the PPA2 survey expect, and wish for, a higher retirement age than those from the PPA1 survey. This is true for men and women alike. What is striking is that the ages given by the respondents show a rise parallel to the increasing life expectancy (cf. Summary 4). The results therefore indicate that respondents are in- 
creasingly anticipating the process of longer survival: to live longer also means to work longer. The postponement of the actual entry into retirement is thus taken into account when people plan their lives. This indicates that there is a particular transit from the model of compressed education and working phases naturally connected with a sooner exit from the labour force, to the model with distributed training and working phases but also with postponed exit from the labour force.

\section{Summary 4:}

Average retirement age-comparison PPA1/PPA2

\begin{tabular}{|l|c|c|c|}
\hline Average retirement age & Total & Men & Women \\
\hline Expected retirement age of non-pensioners PPA2 & 61.8 & 63.0 & 60.1 \\
Desired retirement age of non-pensioners PPA2 & 57.0 & 58.1 & 55.4 \\
Actual retirement age 2001 & 58.0 & 58.7 & 57.3 \\
Life expectancy from birth in 2001 & - & 75.9 & 81,7 \\
Life expectancy at age 60 in 2001 & - & 20.4 & 24,2 \\
& & & 58.0 \\
Expected retirement age of non-pensioners PPA1 & 60.7 & 57.3 & 54.7 \\
Desired retirement age of non-pensioners PPA1 & 56.1 & 58.3 & 57.3 \\
Actual retirement age 1992 & 57.6 & 72.4 & 79.1 \\
Life expectancy from birth in 1992 & - & 18.0 & 22.2 \\
Life expectancy at age 60 in 1992 & - & & \\
\hline
\end{tabular}

Note: The exact wording of the question was: "If you could decide, when would you like to retire./If you could decide, when would you prefer to retire?"

Sources: PPA II, Questions G7 and G8 and Hauptverband 2002; PPA I, Questions 58, 59 and 65; Kytir et al. (2002:748).

If one only looks at the answers given by respondents to the PPA2 survey about the expected retirement age, there are certain differences between the various groups of persons, which, however, are also institutionally conditioned (cf. Summary 5). In Austria, the statutory retirement age is 60 years for women but 65 years for men. Full equalisation will not come into effect until 2033. This difference is likely to be the main explanation why women much more frequently than men expect to go into retirement already before the age of 60. Bigger differences can also be found according to respondents' current age: one third of the 35+ age group, but only one fifth of those $50+$, expect to retire as late as at 65 or even later. There are also considerable differences according to respondents' education level. The trend here is: the more educated respondents are, the more frequently do they assume to go into retirement only after being 60 or 65 , respectively. However, it must be taken into account that education level and age are correlated.

As for the desired retirement age, there are again roughly the same differences by sex and age. Significant differences can be found here as well by the level of education, but also by type of occupation and income. In particular persons with lower education level, lower professional status and lower income would prefer to retire from working life before age 60 . A desired retirement "as early as possible" could be inter- 
preted as a negative comment on unsatisfactory work and employment conditions in the current job. These results therefore also turn the attention towards increased efforts at "humanising the working life". Increasing the actual retirement age needs to be accompanied by certain measures in favour of longer employment.

\section{Summary 5:}

Preferences concerning the transition into retirement, by social characteristics— results of PPA2

\begin{tabular}{|c|c|c|}
\hline Characteristic & Preference $<60$ years & Preference $>60$ years \\
\hline Age $20-34$ & $=$ & $=$ \\
\hline Age $35-49$ & $=$ & $=$ \\
\hline Age $50-64$ & $-/ *$ & $+/ *$ \\
\hline Men & $-/ *$ & $+/ *$ \\
\hline Women & $+/ *$ & $-l^{*}$ \\
\hline Education - lower & $+/^{*}$ & $-/ *$ \\
\hline Education - higher & $-/^{*}$ & $+l^{*}$ \\
\hline Professional status lower & + & - \\
\hline Professional status higher & - & + \\
\hline Income - lower & $+/ *$ & $-l^{*}$ \\
\hline Income - higher & - & + \\
\hline
\end{tabular}

Note: Extent of approval: - below average; + above average; $=$ average. $*=95 \%$ significance level of probability of deviation.

Source: PPA II, Questions G7 and G8.

\section{Conclusions}

The attitudes towards the policy of ageing show that there is an undiminished acceptance of the welfare state. Generally, the responsibility of the state in matters of social policy is deemed to be very high. This is particularly true for the field of old-age provision. At the same time we see that the process of demographic ageing is no longer perceived as negatively as it was ten years ago. Moreover, consequences of demographic ageing are increasingly anticipated. The need for reforms in the pension system is generally recognised, and people expect to have to work longer in the future. Nevertheless, an increase of the retirement age is still not predominantly accepted. At the same time, however, there is large-scale approval of measures for flexible transition into retirement. The survey results thus raise the most central question of how labour market and social policy can be better integrated, in the given economic and demographic circumstances, to allow elderly persons to remain longer in the working process. 
If one takes the PPA results, as well as, e.g., those of a Eurobarometer survey conducted in 2001 (Kohl 2003), as a basis, it becomes quite clear that any promising strategy for prolonging the active working life cannot only consist in raising the age limit and abolishing early retirement, respectively, as envisaged by the pension reform adopted in Austria in summer 2003. ${ }^{7}$ It would rather be necessary to become active in the field of flexibilisation of the transition into retirement in order to bring about an increase in the actual retirement age.

As mentioned above, aside from diminishing numbers in the workforce, the demographic development leads us to expect a structural shift in the age of the working population as well (Coomans 2001; Fent 2003). If one assumes a constant labour force participation rate, however, the workforce supply in Austria will only start diminishing by approx. 2015 (cf. Figure 8 ). ${ }^{8}$ With the given participation rate and at the same time a stagnant economy, increasing the retirement age is bound to entail an aggravation of the situation for elderly persons on the labour market. At least until 2015 it will therefore be necessary to adopt a twofold strategy: on the one hand, the pension system must allow flexible transitions and even early retirements under socially and financially acceptable conditions, while on the other, the employment system must provide the basic requirements for elderly persons to continue working (Naegele 2001; Kommission 2002; Clemens et al. 2003). This requires eliminating age discrimination in the recruitment and human resources policies of firms (Bellmann et al. 2003). Increasing the labour participation of the elderly would also be accompanied by positive effects for the pension system. The elderly do not only constitute the most important resource for stabilising the future workforce supply in terms of quantity (Fuchs 2003), they also form a large political potential for a sustainable consolidation of the pension system (Guger/Mayerhofer 2001; 2003).

A holistic age policy integrating social and employment policies is likely to meet large-scale acceptance in the population. This is corroborated by the PPA results, which on the whole seem to imply that the population is increasingly accommodating to demographic change. Furthermore, the findings indicate that the policy of age-

7 In summer 2003, a pension reform was implemented in Austria. The essential cornerstones of the so-called "pension safeguard reform" are: gradual abolition of early retirement, new regulations for a bonus/malus system, and prolongation of the working life period that the pension is calculated on. This means in fact:

1. Bringing the actual retirement age to the level stipulated by law ( 65 years for males and 60 for females);

2. Reducing the pension payments (by max. $10 \%$ of the current amount) for people who go into retirement early or even at the currently accepted "normal" retirement age.

3. Because of the prolongation of the pension calculation period from 15 to 45 years the pension benefits will be lower. To compensate for losses, it is possible to take out private old-age insurance, which is subsidised by the state.

8 Whether a shortage of the labour force will indeed take place after 2015 is not clear as yet. The process of rationalisation could actually reduce labour demand. For more details of the labour market effects of an ageing labour force, cf. Arnds and Bonin (2003:134ff.). 
ing is also a problem of "social equality" within one generation, rather than solely a problem between young and old. However, the PPA survey does not permit in-depth analysis for the "Ageing" module. This would require a more differentiated and continuous survey programme. ${ }^{9}$ If such an evaluation programme were established, the field of sociological age research in Austria could considerably gain in scientific legitimacy and political relevance.

Figure 8:

Development of the Austrian population at working age (15-64) and of the number of people employed (2000-2050, assuming a constant labour force participation rate)

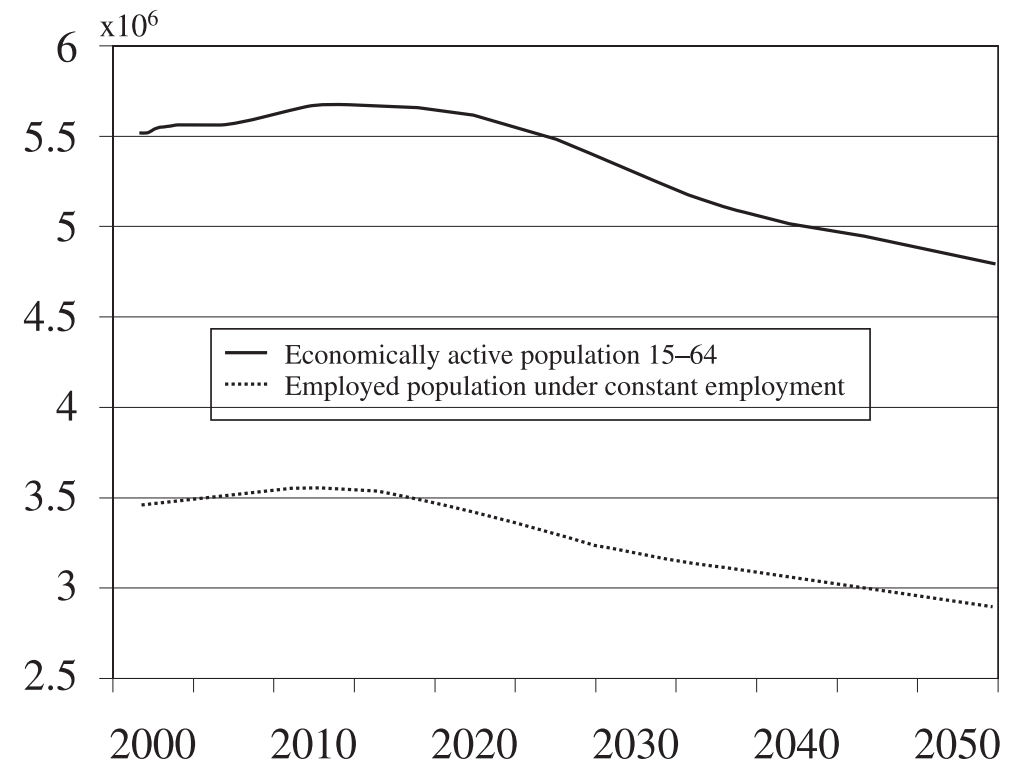

Note: Population projections, Statistics Austria.

Source: Fent (2003).

9 Although participation in the international projects "Share" and "Generations and Gender Survey (GGS)" is intended for 2004, this cannot be considered a alternative to an independent old-age survey. Although the "Survey of Health, Ageing and Retirement in Europe" (Share) does concentrate on the 50+ population groups, it uses a multi-dimensional research design which combines interdisciplinarity, international comparability and a panel approach. The questionnaire, however, is rather heterogenous, giving particular emphasis on health and finances when analysing the life situation of elderly persons (Börsch-Supan et al, 2003). The GGS treats questions concerning old age only at a minor level, so that a differentiated analysis of a number of problematical areas is not possible (Max Planck Institute 2003). What could serve as an example, on the other hand, is the design of the old-age survey recently conducted in Germany (Hoff et al. 2003). 


\section{References}

Arnds, P. and H. Bonin. 2003. Gesamtwirtschaftliche Folgen demographischer Alterungsprozesse. In: Herfurth, Matthias, Martin Kohli and Klaus F. Zimmermann (eds.). Arbeit in einer alternden Gesellschaft. Problembereiche und Entwicklungstendenzen der Erwerbssituation Älterer. Opladen: Leske + Budrich, pp. 131-177.

Avramov, D. and M. Maskova. 2003. Active Ageing in Europe. Volume 1. Population studies, No. 41. Strasbourg: Council of Europe Publishing.

Bellmann, L. et al. 2003. Herausforderungen des demografischen Wandels für den Arbeitsmarkt und die Betriebe. Mitteilungen aus der Arbeitsmarkt- und Berufsforschung 36 (2), pp. 133-149.

Börsch-Supan, A., H. Jürgens and O. Lipps. 2003. Share. Survey of Health, Ageing and Retirement in Europe. Mannheim: Mannheim Institute for the Economics of Aging (MEA).

Clemens, W. 2001. Ältere Arbeitnehmer im sozialen Wandel. Von der verschmähten zur gefragten Humanressource? Opladen: Leske + Budrich.

Clemens, W. et al. (2003): Renaissance der Älteren auf dem Arbeitsmarkt? Schlussfolgerungen und Ausblick zu einer multidisziplinären Forschungsübersicht. In: Herfurth, Matthias, Martin Kohli and Klaus F. Zimmermann (eds.). Arbeit in einer alternden Gesellschaft. Problembereiche und Entwicklungstendenzen der Erwerbssituation Älterer. Opladen: Leske + Budrich, pp. 195-202.

Coomans, G. 2001. Die Alterung der arbeitenden Bevölkerung in Europa: Fragen und Prioritäten. In: Bullinger, Hans-Jörg (ed.). Zukunft der Arbeit in einer alternden Gesellschaft. Stuttgart: Fraunhofer-Institut für Arbeitswirtschaft und Organisation, pp. 48-62.

Fent, T. 2003. Altern und Arbeitsmarkt. Unveröffentlichtes Manuskript. Wien: Institut für Demographie.

Fuchs, J. 2003. Demografische Alterung und Arbeitskräftepotenzial. Unveröffentlichtes Manuskript. Nürnberg: Institut für Arbeitsmarkt- und Berufsforschung.

Guger, A. and C. Mayrhuber. 2001. Arbeitsmarktperspektiven und Pensionsfinanzierung bis 2030. WIFO Monatsberichte 74 (9), pp. 553-565.

Guger, A. and C. Mayrhuber. 2003. Demografische Entwicklungen und Herausforderungen für das österreichische Pensionssystem. In: Neck, Reinhard (ed.). Altern und Alterssicherung aus wissenschaftlicher Sicht. Frankfurt/M.: Lang, pp. 119-139.

Hanika, A. 2001. Bevölkerungsvorausschätzung 2001-2050 für Österreich und die Bundesländer. Statistische Nachrichten 54 (9), pp. 626-637.

Hoff, A. et al. 2003. Die zweite Lebenshälfte - der Alterssurvey zwischen gerontologischer Längsschnittanalyse und Alterssozialberichterstattung im Längsschnitt. In: Karl, Fred (ed.). Sozial- und verhaltenswissenschaftliche Gerontologie. Alter und Altern als gesellschaftliches Problem und individuelles Thema. Weinheim: Juventa, pp. 185-204. 
Kohl, J. 2003. Einstellungen zur Alterssicherung im europäischen Vergleich. Informationsdienst Soziale Indikatoren 29, pp. 1-6.

Kommission der Europäischen Gemeinschaften. 2002. Bericht der Kommission „Erhöhung der Erwerbsbeteiligung und Förderung des aktiven Alterns“. Brüssel.

Konrad, K. and W. Richter. 2003. Zur Berücksichtigung von Kindern bei umlagefinanzierter Alterssicherung. Diskussionspapier SP II 2003-02. Berlin: Wissenschaftszentrum (WZB).

Kytir, J., H. de Wild and P. Zuser. 2002. Demographische Strukturen und Trends 2001. Statistische Nachrichten 55 (10), pp. 736-754.

Max Planck Institute for Demographic Research. 2003. Generations and Gender Progamme. In: http://www.demogr.mpg.de/general/structure/division2/lab-ceffd/ 151.htm

Morschhäuser, M. 1999. Grundzüge altersgerechter Arbeitsgestaltung. In: Gussone, Max et al. (eds.). Ältere Arbeitnehmer: Altern und Erwerbsarbeit in rechtlicher, arbeits- und sozialwissenschaftlicher Sicht. Frankfurt/M.: Bund, pp. 101-186.

Naegele, G. 2001. Demographischer Wandel und Erwerbsarbeit. Aus Politik und Zeitgeschichte B 3-4, pp. 3-4.

Reßler, R. 2002. Bestimmungsfaktoren zur allgemeinen Akzeptanz wohlfahrtsstaatlicher Leistungen. Wirtschaft und Gesellschaft 28 (2), pp. 201-228.

Schimany, P. 2002. Einstellungen zum Altern der Gesellschaft und zur Alterspolitik. Ergebnisse des Population Policy Acceptance Survey (PPA 2). Unveröffentlichter Forschungsbericht. Wien: Institut für Demographie, Österreichische Akademie der Wissenschaften.

Schimany, P. 2003. Der „Population Policy Acceptance Survey II““. In: Gisser, Richard (ed.). Familie, Geschlechterverhältnis, Alter und Migration: Wissen, Einstellungen und Wünsche der Österreicherinnen und Österreicher. Tabellenband und Zusammenfassung ausgewählter Ergebnisse des Population Policy Acceptance Survey 2001 (PPA II). Forschungsbericht 25. Wien: Institut für Demographie, Österreichische Akademie der Wissenschaften, pp. 9-14.

Schmid, J. 2002. Wohlfahrtsstaaten im Vergleich. Soziale Sicherung in Europa: Organisation, Finanzierung, Leistungen und Probleme. Opladen: Leske + Budrich.

Tálos, E. 2003. Sozialstaat Österreich: Probleme und Veränderungen. In: Rosenberger, Sieglinde and Emmerich Tálos (eds.). Sozialstaat. Probleme, Herausforderungen, Perspektiven. Wien: Mandelbaum, pp. 80-95.

Wöss, J. 2002. Perspektiven der Alterssicherung. Wiso 25 (3), pp. 91-113. 